\title{
Biological Effects of Prickly Pear Powder and Extract aginst Tartrazine Toxicity on Experimental Rats
}

\author{
Shimaa F. A. E. Ghozy*
}

Home Economics Dept., Faculty of Specific Education, Mansoura University, Egypt.

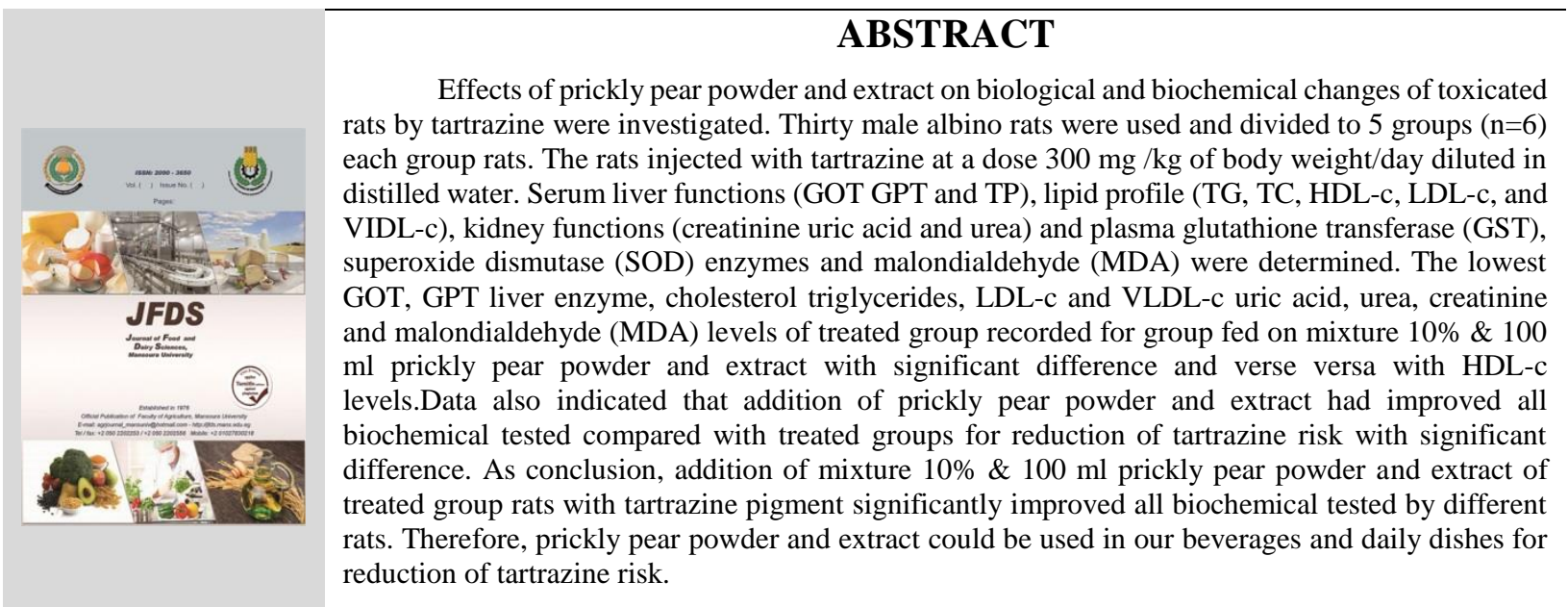

Keywords: Opuntia ficus-indica, dietary fiber, body's immunity, coloring substances.

\section{INTRODUCTION}

The bone fruit called prickly pear " Opuntia ficus-indica " has recently spread. These delicious oval fruits sprout from the tops of thorny aloe vera leaves, ranging in color from yellow-green to deep red or purple (Griffith 2014). Prickly pear is not only a food but also a medicinal remedy for swelling and rheumatism among many indigenous peoples in the southwestern United States and Mexico, whether eaten raw or dried, which makes it a favorite fruit in the hot summer months (Neffar et al., 2013 and Wang et al., 2020). Prickly pear may have a positive effect on blood sugar levels, as it was found that eating prickly pear fruits may help reduce blood sugar levels by $17-48 \%$, which reduces the chances of developing diabetes. Because prickly pears contain a relatively high amount of dietary fiber and various antioxidants, prickly pears regularly may have many benefits for the digestive system and reduce the chances of developing some diseases such as colon cancer and stomach ulcers (Bañuelos et al., 2019).

Prickly pear is rich in potassium, fiber and many other important nutrients for the circulatory system. One of the benefits of prickly pears when eaten regularly may help reduce the chances of developing cardiovascular disease, cholesterol level and blood pressure. And it helps to strengthen the body's immunity, mostly because prickly pears contain relatively high amounts of vit. C and vit. $\mathrm{E}$, in addition to a variety of nutrients and antioxidants and stimulate the production of white blood cells. It is an anti-inflammatory and anti-infection fruit in nature, as it contains chemical compounds that may help prevent infections that may affect muscles or bones as a result of diseases such as arthritis (Kuti 2016 and Nawal et al., 2021). The nutritional value of prickly pears, as each 100 grams of it contains water, protein and fiber ( $\mathrm{g}$ 87.6, 0.73, 3.6) calcium, iron, magnesium, phosphorous, potassium, zinc, sodium, and vit. C (56 $0.385,24,220$, $0.12,5,14 \mathrm{mg}$ ) as well as vit. A, niacin, selenium, and folate acid (Deysi \& Jorge 2007 and Dok-Go et al., 2018).

Tartrazine is one of the Egyptian famous food additives which are used as coloring substances, Moreover, it is used in cooking in many developing countries as a substitute for saffron (Mehedi et al., 2009). Tartrazine known as E102 or FD\&C Yellow 5 is a synthetic lemon yellow azo dye used as a food coloring many products. Medical preparations contain tartrazine such as vitamins, medicinal capsules and certain prescription drugs (Amin et al., 2010). Human studies indicated that tartrazine can induce a wide range of allergic reactions in sensitive or atopic individuals. A variety of immunologic responses have been attributed to tartrazine including: neurobehavioral toxicity, anxiety, migraines, clinical depression, blurred vision, itching, general weakness, heat waves, feeling of suffocation, purple skin patches and sleep disturbances (Hala et al., 2013). Given the current importance of prickly pear as an effective dietary source. The aim of study regarding the biological effects of prickly pear powder and extract against tartrazine poisoning in rats. 


\section{MATERIALS AND METHODS}

\section{Materials}

a-Plant: Prickly pear ficus-indica (Opuntia ficus-indica) dried were from the local company for medicinal plants and herbs, Cairo, Egypt.

b-Tartrazine: was purchased from any local company for cosmetics, Cairo, Egypt.

c-Rats and diet: Thirty adult male albino rats (SpragueDawley strain) weigh averaged (140-150g) will be obtained from the animal colony, Helwan farm, Vaccine and Immunity Organization, Ministry of Health, Cairo, Egypt. Stander basal diet were consists of casein ( $\geq 80 \%$ protein) $14 \%$, cellulose $5 \%$, soybean oil $4 \%$, salt mixture $3.5 \%$, vitamin mixture $1 \%$, choline chloride $0.25 \%$, DLmethionine $0.3 \%$ and corn starch up to $100 \mathrm{~g}$ according to (Hegsted et al., 1941; Campbell 1963 and Reeves et al., 1993).

\section{Methods:}

-Preparation of prickly pear powder: Wash the prickly pear seeds well, grind and leave to dry at room temperature.

-Preparation of prickly pear extract:

Extraction of the alcoholic aqueous extract according to (Charles et al., 1993).

-Chemical constituents of prickly pear powder: Moisture, protein, crude fibers, fat content and ash contents were described in the (A.O.A.C 2000).

\section{-Experimental rats design:}

Rats will be kept in clean wire cages under hygienic conditions in a room maintained at a relative humidity 40 $60 \%, 20-25^{\circ} \mathrm{C}$ and $12 / 12 \mathrm{~h}$ day light/darkness cycle. Adaptation will be continued for one week. After that, rats will be randomly assigned to five groups as follows: Group (1): fed only on basal diet as a negative control group. Group (2): fed on basal diet with tartrazine-intoxicated, $300 \mathrm{mg} / \mathrm{kg}$ of body weight/day by oral route (El Golli et al., 2016) as positive control group, treated groups Group (3): Intoxicated with tartrazine and fed on basal diet containing prickly pear powder $10 \%$ wet /diet /day. Group (4): Intoxicated with tartrazine and on basal diet containing Prickly pear extract 100 $\mathrm{ml} / \mathrm{kg}$ of body wet/day. Group (5): Intoxicated with tartrazine and fed on basal diet containing mixture $10 \%$ prickly pear powder and Prickly pear extract $100 \mathrm{ml} / \mathrm{kg}$ of body wet/day.

The experiment will continue for 30 days. animals were sacrificed. Body weights were measured three times a week. Daily changes in body weights was percentages. Food efficiency ratio (FER) was calculated at the end of experiment.

-Serum lipid profiles: Serum total cholesterol (TC), triglycerides (TG), high density lipoprotein cholesterol (HDL-C) according to (Toklu et al., 1969) (low density lipoprotein cholesterol "LDL-C" and very low density lipoprotein cholesterol "VLDL-C" will be calculated) (Lee and Nieman 1996).

-Liver function: Serum including transaminases (AST and ALT) and alkaline phosphatase (ALP) according to (Clinica 1980; Hafkenscheid 1979 and Moss 1982).

-Kidney functions: Serum creatinine and urea nitrogen in serum according to (Henry 1974).

-Determination of some antioxidant parameters: Superoxide dismutase (SOD) activity by (Dechatelet et al.,
1974). Determination of malondialdehyde (MDA) in red blood cells RBCs by the method described by (Stocks and Donnandy 1971). Glutathione (GSH) according to (Beutler 1984).

-Statistical analysis: Statistical analysis will be carried out using one way analysis of variance (ANOVA) test followed by Duncan test through the programmed of statistical packages for the social science (SPSS). Results will be expressed as mean $\pm \mathrm{SD}$. The differences among means at $\mathrm{p}<$ 0.05 will be considered significant (Snedecor and Cochran 1989).

\section{RESULTS AND DISCUSSION}

The chemical composition of raw prickly pear powder is illustrated in Table (1). The main constituents of raw prickly pear powder were moisture, protein, fat, ash, carbohydrate and crude fiber were $(9.2,1.4,0.8,5.7,8.2$ and $74.7 \mathrm{~g} / 100 \mathrm{~g}$ ) respectively. The results of elementary chemical composition of prickly pear agreed with those reported by (Grigson 2007; Jump \& Katie 2010 and Bañuelos et al., 2019). The obtained results in Table (2) indicated that tartrazine toxicity $(\mathrm{ve}+)$ control group recorded significantly lower in food intake (FI), body weight and gain\% (BWG\%) in comparison of normal control group. Animals treated with prickly pear as concentrations (10\%, $100 \mathrm{ml}$ and mixture) showed significantly reduction in $(\mathrm{FI})$, and $(\mathrm{BWG} \%)$ in comparing with normal control group. While showed significant higher in (FI), and (BWG\%) in comparing with tartrazine toxicity (ve + ) control group. These results may be as a result of nutritional values of prickly pear because of an excellent source of vitamins and mineral. Also, prickly pear is rich source of flavonoids which improve the biological functions for its antioxidant properties. That prickly pear high bioavailability is partially because of its low content of trypsin inhibitors and reduce protein enzymatic digestion and absorption (Deysi \& Jorge 2007 and Dok-Go et al., 2018).

Table 1. Chemical composition of prickly pear powder (g/100g dry weight basis) \%

\begin{tabular}{lllll}
\hline & & & \\
Prickly \\
pear
\end{tabular}

Table 2. Mean values \pm SD of body weight gain (BWG), food intake (FI) and FER of the experimental rat groups

\begin{tabular}{lccc}
\hline \multicolumn{1}{c}{ Treatment Parameter } & $\begin{array}{c}\text { BWG } \\
(\mathbf{g})\end{array}$ & $\begin{array}{c}\text { FI } \\
(\mathbf{g} / \mathbf{d a y})\end{array}$ & $\begin{array}{c}\text { FER } \\
(\mathbf{\%})\end{array}$ \\
\hline Group 1: Control group (-) & $25.60 \pm 0.30^{\mathrm{e}}$ & $15.05 \pm 1.12^{\mathrm{a}}$ & $0.071 \pm 0.001 \mathrm{a}$ \\
Group 2: Control group(+) & $19.71 \pm 0.12^{\mathrm{c}}$ & $12.35 \pm 1.13^{\mathrm{c}}$ & $0.041 \pm 0.002 \mathrm{c}$ \\
Group 3 & $21.90 \pm 0.10^{\mathrm{b}}$ & $14.47 \pm 1.05^{\mathrm{b}}$ & $0.071 \pm 0.001 \mathrm{ab}$ \\
Group 4 & $23.15 \pm 0.20^{\mathrm{b}}$ & $14.12 \pm 1.11^{\mathrm{b}}$ & $0.067 \pm 0.005 \mathrm{~b}$ \\
Group 5 & $24.75 \pm 0.41^{\mathrm{a}}$ & $15.15 \pm 1.10^{\mathrm{a}}$ & $0.067 \pm 0.003 \mathrm{~b}$ \\
LSD & 3.42 & 1.58 & 0.020 \\
\hline
\end{tabular}

Mean under the same column bearing different superscript letters are different significantly $(\mathrm{p} \leq \mathbf{0 . 0 5})$.

The effect of prickly pear powder and extract against tartrazine toxicity on liver functions rats are shown in Table (3). It is clear to notice that the positive control group of AST 
liver enzyme recorded the higher level compared with negative control group with significant differences, which were $60.0 \pm 6.0$ and $32.0 \pm 2.0 \mathrm{U} / \mathrm{L}$ respectively. On the other hand, in treated rats the highest ALT liver enzyme levels recorded for intoxicated rats with tartrazine and fed on basal diet containing mixture $10 \% \& 100 \mathrm{ml}$ prickly pear powder and extract while, the lowest ALT liver enzyme levels recorded for rats fed on basal diet containing mixture $10 \%$ \&100 ml prickly pear powder and extract with significan difference $(\mathrm{P} \leq 0.05)$. These results were in accordance with Kuti (2016) who reported that chronic prickly pear supplementation alleviated oxidative injury of the liver and improved the hepatic structure and function in rats exposed to bile duct ligation. Another study by Esposito et al., (2020) they found that in rats with carbon tetrachloride-induced liver damage demonstrated that pretreatment with prickly pear extract resulted in the reduction of lipid peroxidation, while the free-radical scavenging activity of CAT, SOD, and peroxidase were significantly enhanced.

Table 3. Mean values \pm SD of serum amino transferase (AST \& ALT), and total protein of the experimental rats groups

\begin{tabular}{lccc}
\hline Treatment Parameter & $\begin{array}{c}\text { AST } \\
(\mathbf{U} / \mathbf{L})\end{array}$ & $\begin{array}{c}\text { ALT } \\
(\mathbf{U} / \mathbf{L}\end{array}$ & $\begin{array}{c}\text { Total Protein } \\
(\mathbf{m g} / \mathbf{d l})\end{array}$ \\
\hline Group 1: Control group (-) & $32.00 \pm 20^{\mathrm{d}}$ & $27.00 \pm 4.9^{\mathrm{d}}$ & $6.98 \pm 0.13^{\mathrm{a}}$ \\
Group 2: Control group (+) & $60.00 \pm 6.0^{\mathrm{a}}$ & $52.00 \pm 1.5^{\mathrm{a}}$ & $3.00 \pm 0.53^{\mathrm{d}}$ \\
Group 3 & $48.00 \pm 1.0^{\mathrm{b}}$ & $35.60 \pm 12^{\mathrm{b}}$ & $5.15 \pm 0.44^{\mathrm{b}}$ \\
Group 4 & $45.50 \pm 1.5^{\mathrm{b}}$ & $31.00 \pm 1.8^{\mathrm{bc}}$ & $5.74 \pm 0.80^{\mathrm{b}}$ \\
Group 5 & $42.00 \pm 15^{\mathrm{c}}$ & $29.10 \pm 8.5^{\mathrm{c}}$ & $6.27 \pm 0.19^{\mathrm{a}}$ \\
LSD (P $\leq 0.05)$ & 3.550 & 3.102 & 0.925 \\
\hline
\end{tabular}

Mean under the same column bearing different superscript letters are different significantly $(p \leq 0.05)$.AST: Aspartate aminotransferase ALT :Alanine aminotransferase

The effect of prickly pear powder and extract against tartrazine toxicition on the serum total cholesterol and triglycerides of experimental rats are shown in Table (4). The obtained results indicated that the cholesterol levels of positive control group recorded the higher value when compared with negative control group with significant difference $(\mathrm{P} \leq 0.05)$. The mean values were $119 \pm 7.0$ and $102.50 \pm 3.0 \mathrm{mg} / \mathrm{dl}$, respectively. While, rats intoxicated with tartrazine and fed on basal diet containing mixture $10 \%$ \&100 $\mathrm{ml}$ prickly pear powder and extract recorded the lowest serum T.G and T.Ch levels with significant difference $(\mathrm{P} \leq 0.05)$. Amin et al., (2010) observed significant increases in serum total lipids, cholesterol and triglycerides in rats whose diets were supplemented with chocolate colours A and B that tartrazine and carmoisine were among of them (sunset yellow, tartrazine, carmoisine and brilliant blue) in varying concentrations. Esposito et al., (2020) demonstrated that administration of hydroethanolic extract from prickly pear showed marked antihyperlipidemic effects in high lipid diet fed rats. Prickly pear decreased serum cholesterol, triglycerides, these due to the different parts of prickly pear have been known as a reservoir of bioactive compounds with potential biological activities. Prickly pear especially the leaves of decreased the dyslipidemia of obesity and cardiovascular risk factors.

The obtained results indicated that the high density lipoprotein (HDL-c) levels of positive control group recorded the higher value when compared with negative control group with significant difference $(\mathrm{P} \leq 0.05)$. The mean values were $49.0 \pm 2.0$ and $30.50 \pm 1.5 \mathrm{mg} / \mathrm{dl}$, respectively. Data also showed that, rats intoxicated with tartrazine and fed on basal diet containing $10 \% \& 100 \mathrm{ml}$ prickly pear powder and extract groups recorded the lowest (HDL-c) levels, while the highest (HDL-c) levels value recorded for rats fed on basal diet containing mixture $10 \%$ \& $100 \mathrm{ml}$ prickly pear powder and extract significant difference $(\mathrm{P} \leq 0.05)$.

Table 4. Mean values \pm SD of serum lipid profile of the experimental rats groups

\begin{tabular}{|c|c|c|c|c|c|}
\hline $\begin{array}{l}\text { Treatment } \\
\text { Parameter }\end{array}$ & $\begin{array}{c}\text { TC } \\
(\mathbf{m g} / \mathbf{d l})\end{array}$ & $\underset{(\mathrm{mg} / \mathrm{dl})}{\text { TG }}$ & $\begin{array}{c}\left(\text { HDL }_{-C}\right) \\
(\mathbf{g} / \mathbf{d l})\end{array}$ & $\begin{array}{c}\text { (LDL- } \\
\text { c) } \\
(\mathrm{g} / \mathrm{dl})\end{array}$ & $\begin{array}{c}\text { (VLDL_c) } \\
(\mathrm{g} / \mathrm{dl})\end{array}$ \\
\hline Group 1 : Control & $94.0 \pm$ & $\begin{array}{c}62.00 \pm \\
10^{\mathrm{d}}\end{array}$ & $\begin{array}{c}49.0 \pm \\
20^{\mathrm{a}}\end{array}$ & $\begin{array}{l}36.60 \pm \\
4.50^{\mathrm{e}}\end{array}$ & $\begin{array}{c}12.40 \pm \\
02^{\mathrm{d}}\end{array}$ \\
\hline $\begin{array}{l}\text { Group 2: Control } \\
\text { group }(+)\end{array}$ & $\begin{array}{c}119.0 \pm \\
7.0^{\mathrm{a}}\end{array}$ & $\begin{array}{c}102.50 \pm \\
3.5^{\mathrm{a}}\end{array}$ & $\begin{array}{c}30.50 \pm \\
1.50^{\mathrm{e}}\end{array}$ & $\begin{array}{c}68.10 \pm \\
4.0^{\mathrm{a}}\end{array}$ & $\begin{array}{c}20.40 \pm \\
0.7^{\mathrm{a}}\end{array}$ \\
\hline Group 3 & $\begin{array}{l}107.5 \pm \\
5.5^{\mathrm{b}}\end{array}$ & $\begin{array}{c}96.20 \pm \\
4.5^{\mathrm{b}}\end{array}$ & $\begin{array}{c}36.00 \pm \\
1.0^{\mathrm{d}}\end{array}$ & $\begin{array}{l}60.26 \pm \\
3.0^{\mathrm{b}}\end{array}$ & $\begin{array}{l}17.24 \pm \\
0.3^{\mathrm{b}}\end{array}$ \\
\hline Group 4 & $\begin{array}{c}104.50 \pm \\
6.5^{\mathrm{bc}}\end{array}$ & $\begin{array}{l}93.50 \pm \\
2.5^{\mathrm{b}}\end{array}$ & $\begin{array}{c}42.50 \pm \\
1.50^{c}\end{array}$ & $\begin{array}{l}58.70 \pm \\
5.0^{c}\end{array}$ & $\begin{array}{l}16.30 \pm \\
0.5^{\mathrm{b}}\end{array}$ \\
\hline Group 5 & $\begin{array}{l}96.50 \pm \\
1.05^{\mathrm{d}}\end{array}$ & $\begin{array}{c}86.50 \pm \\
1.5^{\mathrm{c}}\end{array}$ & $\begin{array}{l}46.00 \pm \\
2.50^{b}\end{array}$ & $\begin{array}{l}40.50 \pm \\
7.0^{\mathrm{d}}\end{array}$ & $\begin{array}{c}15.00 \pm \\
0.7^{\mathrm{c}}\end{array}$ \\
\hline $\operatorname{LSD}(\mathrm{P} \leq 0.05)$ & 5.731 & 4.352 & 4.230 & 3.151 & 1.062 \\
\hline
\end{tabular}

Mean under the same column bearing different superscript letters are different significantly $(\mathbf{p} \leq \mathbf{0 . 0 5})$.TC: Cholesterol TG: Triglyceride HDLc: High density lipoprotein cholesterol LDLc: Low density lipoprotein cholesterol VLDLc: Very low density lipoprotein cholesterol

Data also indicated that the LDL-c and VLDL-c levels of positive control group recorded the higher value when compared with negative control group with significant difference $(\mathrm{P} \leq 0.05)$. The mean values were $68.10 \pm 4.0$ and $20.40 \pm 4.5 \mathrm{mg} / \mathrm{dl}$, respectively. While, rats intoxicated with tartrazine and fed on basal diet containing $10 \%$ \& $100 \mathrm{ml}$ prickly pear powder and extract groups recorded the highest LDL-c and VLDL-c levels, while the lowest LDL-c and VLDL-c levels value recorded for rats fed on basal diet containing $10 \%$ \& $100 \mathrm{ml}$ prickly pear powder and extract significant difference $(\mathrm{P} \leq 0.05)$. These results are in harmony with Esposito et al., (2020) they reported that the greatest mechanism of prickly pear powder which include ellagic acid that combating cholesterol is associated with an enzyme known as ellagic acid is an HDL-associated enzyme whose activity is related to cholesterol and atherosclerosis, decreased activity of ellagic acid may be related to its ability to protect against lipid peroxidation.

Data in Table (5) show the effect of prickly pear against tartrazine toxicition on the kidney functions creatinine, uric acid and urea level of experimental rats. It is clear to notice that the creatinine, uric acid and urea levels of positive control group recorded the higher value when compared with negative control group with significant difference $(\mathrm{P} \leq 0.05)$. The mean values were $1.29 \pm 0.14$, $3.50 \pm 0.25 \& 35.50 \pm 5.0 \mathrm{mg} / \mathrm{dl}$, respectively. While, the lowest urea levels recorded for rats intoxicated with tartrazine and fed on basal diet $10 \%$ \& $100 \mathrm{ml}$ prickly pear powder, extract and mixture $10 \% \& 100 \mathrm{ml}$ prickly pear powder and extract groups with significant difference $(\mathrm{P} \leq 0.05)$.

This is in agreement with Dok-Go et al., (2018) who reported that prickly pear have been shown to attenuate the renal dysfunction, improve the renal architecture, with nearly normalization of serum urea and creatinine levels which indicate improvement of renal function. 
Table 5. Mean values \pm SD of serum kidney function of the experimental rats groups

\begin{tabular}{lccc}
\hline $\begin{array}{l}\text { Treatmen } \\
\text { Parameter }\end{array}$ & $\begin{array}{c}\text { Creatinine } \\
(\mathbf{m g} / \mathbf{d l})\end{array}$ & $\begin{array}{c}\text { Uric acid } \\
(\mathbf{m g} / \mathbf{d l})\end{array}$ & $\begin{array}{c}\text { Urea } \\
(\mathbf{m g} / \mathbf{d l})\end{array}$ \\
\hline Group 1: & $0.50 \pm 0.13^{\mathrm{c}}$ & $1.75 \pm 0.15^{\mathrm{e}}$ & $18.50 \pm 3.5^{\mathrm{f}}$ \\
Control group (-) & & & \\
Group 2: & $1.29 \pm 0.14^{\mathrm{a}}$ & $3.50 \pm 0.25^{\mathrm{a}}$ & $35.50 \pm .5 .0^{\mathrm{a}}$ \\
Control group (+) & $1.07 \pm 0.14^{\mathrm{b}}$ & $2.80 \pm 0.20^{\mathrm{c}}$ & $29.00 \pm 1.0^{\mathrm{d}}$ \\
Group 3 & $0.80 \pm 0.20^{\mathrm{b}}$ & $2.50 \pm 0.40^{\mathrm{d}}$ & $24.0 \pm 1.0^{\mathrm{e}}$ \\
Group 4 & $0.60 \pm 0.02^{\mathrm{a}}$ & $1.90 \pm 0.09^{\mathrm{b}}$ & $20.50 \pm 5.50^{\mathrm{b}}$ \\
Group 5 & 0.261 & 0.302 & 1.321 \\
\hline LSD (P $\leq 0.05)$ & & & \\
\hline
\end{tabular}

Mean under the same column bearing different superscript letters are different significantly $(p \leq 0.05)$.

Data in Table (6) show the effect of prickly pear against tartrazine toxicition on the plasma superoxide dismutase (SOD), glutathione transferase (GST), enzymes and Malondialdehyde (MDA) level of experimental rats. Table (10) presented that positive control group showed a significant decrease in SOD and GST while showed a significant increase in MDA compared with normal control group. The mean values were $114.33 \pm 12.01 \mathrm{U} / \mathrm{mL}$, $1.17 \pm 0.55 \mathrm{nmol} / \mathrm{L} \& 12.35 \pm 1.16 \mathrm{nmol} / \mathrm{L}$ respectively. While, the lowest urea levels recorded for rats intoxicated with tartrazine and fed on basal diet $10 \%$ \& $100 \mathrm{ml}$ prickly pear powder, extract and mixture $10 \% \& 100 \mathrm{ml}$ prickly pear powder and extract groups with significant difference $(\mathrm{P} \leq 0.05)$.

Table 6. Mean values \pm SD of plasma glutathione transferase (GST), superoxide dismutase (SOD) enzymes and Malondialdehyde (MDA) of the experimental rats groups.

\begin{tabular}{lccc}
\hline $\begin{array}{l}\text { Treatmen } \\
\text { tParameter }\end{array}$ & SOD U/mL & $\begin{array}{c}\text { GSTmmol/ } \\
\mathbf{L}\end{array}$ & $\begin{array}{c}\text { MDA } \\
\mathbf{~ m m o l} / \mathbf{L}\end{array}$ \\
\hline $\begin{array}{l}\text { Group 1: } \\
\text { Control group (-) }\end{array}$ & $176.23 \pm 12.74 \mathrm{a}$ & $3.38 \pm 0.75 \mathrm{a}$ & $4.47 \pm 0.76 \mathrm{~d}$ \\
Group 2: & $114.33 \pm 12.01 \mathrm{~d}$ & $1.17 \pm 0.55 \mathrm{~d}$ & $12.35 \pm 1.16 \mathrm{a}$ \\
Control group (+) & & & \\
Group 3 & $142.12 \pm 13.01 \mathrm{c}$ & $1.98 \pm 0.65 \mathrm{c}$ & $7.21 \pm 0.96 \mathrm{~b}$ \\
Group 4 & $148.33 \pm 14.81 \mathrm{bc}$ & $2.58 \pm 0.80 \mathrm{~b}$ & $6.37 \pm 0.52 \mathrm{~b}$ \\
Group 5 & $166.01 \pm 14.10 \mathrm{~b}$ & $2.91 \pm 0.09 \mathrm{~b}$ & $5.11 \pm 0.37 \mathrm{c}$ \\
\hline LSD $(\mathrm{P} \leq 0.05)$ & 0.261 & 0.302 & 1.321 \\
\hline
\end{tabular}

Mean under the same column bearing different superscript letters are different significantly $(\mathrm{p} \leq \mathbf{0 . 0 5})$.

These results are in parallel with those obtained by

Wang et al., (2020) who revealed that natural anti-oxidants have an important role in inhibiting free radicals and oxidative series reactions at the tissue and membrane levels. Moreover, the addition of prickly pear to the diet affected oxidative status by lowering levels of malondialdehyde (MDA) and antioxidant enzyme activity in the body. In conclusion, feeding rats prickly pear powder and extract as concentrations $(10 \%$ and $100 \mathrm{ml}$ ) may significantly reduce oxidative stress and enhance the antioxidant defense status against tartrazine poisoning in rats. So this study recommends the use of prickly pear for humans suffering oxidative stress, could be of value and safe.

\section{REFERENCES}

Amin, K.A.; Abdel Hameid, H. and AbdElsttar, A.H. (2010): Effect of food azo dyes tartrazine and carmoisine on biochemical parameters related to renal, hepatic function and oxidative stress biomarkers in young male rats. Food and Chemical Toxicology, (48):2994-2999.

AOAC, (2000): Association of Official Agricultural Chemists. Official Method of Analysis. 17th Ed. Vol. 11. Washington U.S. A.

Bañuelos, G.S., Fakra, S.C., Walse, S.S., Marcus, M.A., Yang, S.I., Pickering, I.J., Pilon-Smits, E.A., and Freeman, J.L. (2019): Selenium Accumulation, Distribution, and Speciation in Spineless Prickly pear Prickly pear: a Drought- and Salt-Tolerant, SeleniumEnriched Nutraceutical Fruit Crop for Biofortified Foods". Plant Physiology. 155 (1): 415-427.

Beutler, E. (1984): Red cell metabolism. Third edition, J. Grune and Startton, New York, 131-132; 74-6.

Campbell, J.A. (1963): Methodology of protein evaluation: a critical appraisal of methods for evaluation of protein in foods. RAG Nutr. Document R. 101 Add.37, June Meeting, New York.

Charles, D.J.; Morales; R.; and Simon, E. (1993): Essential oil content and chemical composition of hydroalcoholic extract of Vitellaria Paradoxa, New crops, 5703.

Clinica Chimica Acta (1980): 105, 147-172. (Chemical kits).

Dechatelet, L. R.; Mc Call, C. E.; Mc Phial, L. C. and Johnston, R. B. (1974): Superoxide dismutase activity in leukocytes. J. Clin. Invest., 53: 1197-1201.

Deysi Guzmán Loayza, and Jorge Chávez (2007): Estudio bromatológico del cladodio del nopal (Opuntia ficusindica) para el consumo humano. Chemical compositional study of nopal (Opuntia ficusindica) cladophyll for human consumption. Revista de la Sociedad Química del Perú versión impresa ISSN 1810-634X.

Dok-Go Hyang; Heun Lee Kwang; Ja Kim Hyoung; Ha Lee Eun; Lee Jiyong; Seon Song Yun; Lee Yong-Ha; Jin Changbae; Sup Lee Yong; and Cho Jungsook (2018): Neuroprotective effects of antioxidative flavonoids, quercetin, (+)-dihydroquercetin, and quercetin 3methyl ether, isolated from Opuntia ficus-indica var. saboten". Brain Research. 965 (1-2): 130-136.

El Golli, N.; Bini-Dhouib, I.; Jrad, A.; Boudali, I.; Nasri, B.; Belhadjhmida, N. and ElFazaa, S. (2016): Toxicity induced after subchronic administration of the synthetic food dye tartrazine in adult rats, role of oxidative stress. Recent Advances in Biology and Medicine, 2:20-28.

Esposito, T. Silva, N. H. C. S. Almeida, A. Silvestre, A. J. D. Piccinelli, A. Aquino, R. P. Sansone, F. Mencherini, T. Vilela, C. and Freire, C. S. R. (2020): Ind. Crop. Prod. 151, 112491-112514.

Griffith, M. P. (2014): The Origins of an Important Prickly pear Crop, Opuntia ficus-indica (Cactaceae): New Molecular Evidence. American Journal of Botany. 91 (11): 1915-1921.

Grigson, Jane (2007): Jane Grigson's Fruit Book. U of Nebraska Press 380. ISBN 978-0-8032-5993-5. 
Hafkenscheid, J.C. (1979): Determination of GOT. Clin. Chem., 25:155.

Hala, M. and Salha, A. (2013): Protective action of vitamin C against mutagenic effects of synthetic food color tartrazine. African Journal of Pharmacy and Pharmacology, 7(35): 2474-2483.

Hegsted, D. M.; Mills, R. C.; Elvehjem, C. A. and Hart, E. B. (1941): Choline in the nutrition of chicks. J. Biol. Chem., 138:459-466.

Henry, R.J. (1974): Clinical Chemist: Principles and Techniques, $2^{\text {nd }}$ Edition, Hagerstoun (MD), Harcer, ROW, 882-295.

Jump Lyle, and Katie Letcher (2010): The Complete Guide to Edible Wild Plants, Mushrooms, Fruits, and Nuts: How to Find, Identify, and Cook Them (2nd ed.). Guilford, CN: FalconGuides. 168.

Kuti Joseph O. (2016): Antioxidant compounds from four Opuntia cactus pear fruit varieties". Food Chemistry. 85 (4): 527-533.

Lee, R. and Nieman, D. (1996): Nutrition Assessment. $2^{\text {nd }}$ Ed., Mosby, Missouri, MI.

Mehedi, N.; Ainad-Tabet, S.; Mokrane, N.; Addou, S.; Zaoui, C.; Kheroua, O. and Saidi, D. (2009): Reproductive toxicology of tartrazine (FD and C Yellow No. 5) in Swiss albino mice. American Journal of Pharmacology and Toxicology, 4(4):128-133.

Moss, D.W. (1982): Alkaline phosphatase isoenzymes. Clin. Chem. 28: 2007-2016.
Nawal Makhloufi, Nadia Chougui, Farouk Rezgui, Elias Benramdane, Carmen S. R., Freire, Carla Vilela, and Armando J. D. Silvestre (2021): Bio-based sustainable films from the Algerian Opuntia ficusindica cladodes powder: Effect of plasticizer content. J Appl Polym Sci, 138:e50450.

Neffar, S., Chenchouni, H., Beddiar, A., and Redjel, N. (2013): Rehabilitation of Degraded Rangeland in Drylands by Prickly pear (Opuntia ficus-indica L.) Plantations: Effect on Soil and Spontaneous Vegetation". Ecologia Balkanica. 5, 22-40.

Reeves, P. G.; Nielsen, F. H. and Fahey, G. C. (1993): AIN93 purified diets for laboratory rodents: Final report of the American Institute of Nutrition Ad Hoc Writing Committee on the Reformulation of the AIN-76A Rodent Diet. J. Nutr., 123 (11): 1939-1951.

Snedecor, G. W. and Cochran, W. G. (1989): Statistical Methods. $8^{\text {th }}$ ed., Iowa State University Press, Ames, Iowa 50014, USA.

Stocks, J. and Donnandy, J. (1971): The autoxidfation of human red cell lipids induced by hydrogen peroxide. Br. J. Haematol., 20: 95-111.

Toklu, H.Z.; Dumlu, M.U.; Sehirli, O.; Ercan, F.; Gedik, N.; Tinder, P. (1969): Determination of triglycerides. Ann. Clin. Biochem., 6: 24 - 27.

Wang, R. Liu, X. Li, L. Chen, W. Bai, J. Ma, F. Liu, X. and Kang, W. (2020): Polym. Test. 90, $106708-106715$.

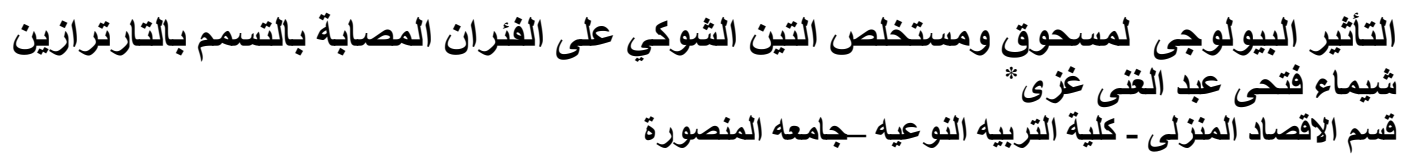

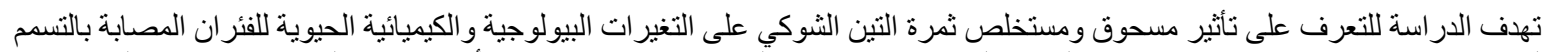

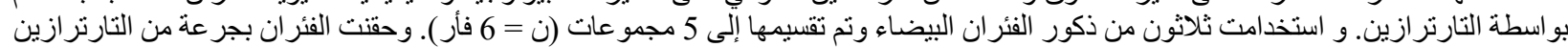

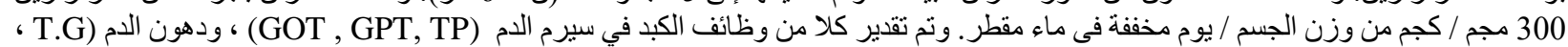

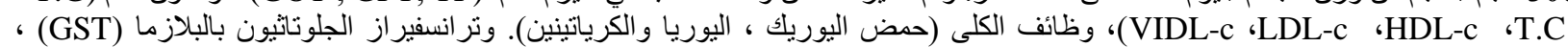

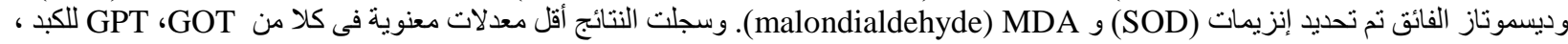

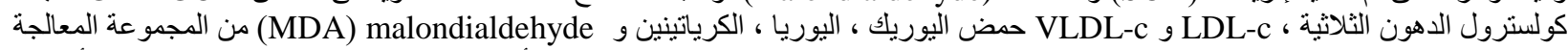

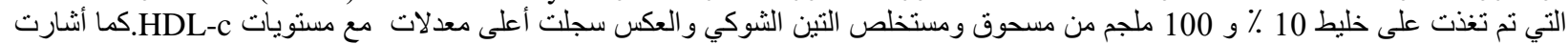

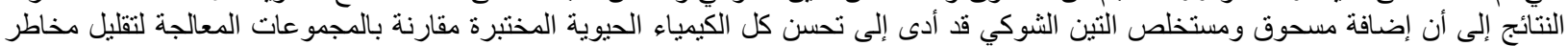

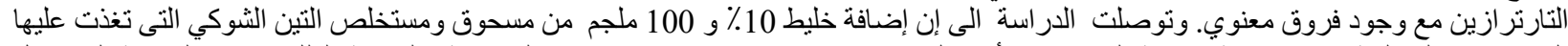

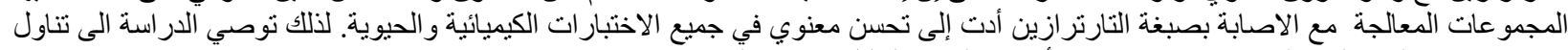

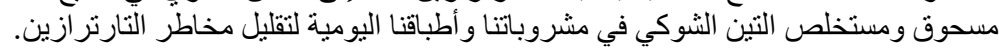
الكلمات الأفتتاحية : التين الثوكي ، الألياف الغذائية ، مناعة الجسم ، مو ادئ تلوين. 